\title{
Spectrophotometric method for the determination of the $\mathrm{pH}_{\mathrm{T}}$ of sea water
}

\author{
Nolwenn Lamandé ${ }^{a}$, Florence Salvetat, Caroline Le Bihan, Laurent Delauney \\ IFREMER, Institut français de recherche pour l'exploitation de la mer, LDCM, Centre de Bretagne, Technopôle de Brest Iroise, 29280 \\ Plouzané, France
}

\begin{abstract}
Résumé: cet article présente la méthode spectrophotométrique mise en place au laboratoire de métrologie de l'Ifremer, afin de déterminer le $\mathrm{pH}_{\mathrm{T}}$ de l'eau de mer grâce à l'indicateur coloré pourpre de $m$-cresol. Le but est de décrire précisément cette méthode (matériel et mode-opératoire), ses difficultés, ainsi que les paramètres ayant un impact sur le $\mathrm{pH}_{\mathrm{T}}$. Les résultats d'une comparaison inter-laboratoires menée par le JAMSTEC (Japan Agency for Marine-Earth Science and Technology) seront présentés, suivis d'une réflexion portant sur cette méthode ainsi que les exigences océanographiques mises en jeu.
\end{abstract}

\section{Introduction}

In the field of oceanography, the $\mathrm{pH}$ of sea water plays an essential role in the ocean's carbon cycle. Carbone dioxide emissions are the major cause of the acidification of oceans which absorb a part of these emissions. That is why the monitoring of ocean $\mathrm{pH}$ is more and more addressed in International, European and national projects. The oceanographic need in terms of measurement is around \pm $0.004 \mathrm{pH}$ unit. In this framework, the metrology laboratory of Ifremer has collaborated to several projects like the Joint Research Project ENV05 OCEAN [1] and AQUAREF (National collaboration concerning the monitoring of water environments). Among other things, our collaborations focus on the qualification of the spectrophotometric $\mathrm{pH}_{\mathrm{T}}$ measurements.

Contrary to fresh water, $\mathrm{pH}$ measurements of sea water are affected by the presence of salts. That is why several distinct $\mathrm{pH}$ scales exist:

- The NBS or NIST scale: the pH measured using the NIST scale is based only on the concentration of free hydrogen ions. To model the scale, the International Union of Pure and Applied Chemistry defined a series of buffer solutions across a range of $\mathrm{pH}$ values. However, these solutions can only be used as reference for fresh water because of their low ionic strength. There are not suitable for oceanographic environment.

- To resolve this problem, in sea water, another $\mathrm{pH}$ scale is used, which is named the Total $\mathrm{pH}$ scale: $\mathrm{pH}_{\mathrm{T}}$. This scale is based on the measurement of free hydrogen ions and the hydrogen ions combined to sulphate $\left(\mathrm{H}^{+}+\mathrm{HSO}_{4}^{-}\right)$.
- Another scale named the Sea Water Scale exists:

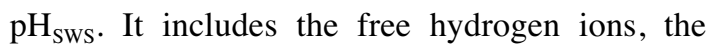
hydrogen ions combined to sulphate, and the hydrogen ions combined to fluoride $\left(\mathrm{H}^{+}+\mathrm{HSO}_{4}^{-}\right.$ $+\mathrm{HF}$ ). Nevertheless, hydrogen ions combined to fluoride are in insignificant concentration in sea water (more than 400 times less concentrated than the sulphate ions); so, the difference between the $\mathrm{pH}_{\mathrm{T}}$ scale and the $\mathrm{pH}_{\mathrm{Sws}}$ scale is very small. That is why scientists are more focussed on $\mathrm{pH}_{\mathrm{T}}$ measurements.

One of the methods for measuring the $\mathrm{pH}_{\mathrm{T}}$ of sea water is the use of $m$-cresol purple indicator dye and spectrophotometric analysis. We propose in this document, to describe the equipment and procedure set up at Ifremer metrology laboratory to determine the $\mathrm{pH}_{\mathrm{T}}$ of sea water using this method. We will finally present the results obtained in an inter-laboratory comparison organized by JAMSTEC (Japan Agency for Marine-Earth Science and Technology).

\section{Ifremer metrology laboratory facilities}

For more than twenty years, the metrology laboratory of Ifremer has been performing calibrations on several oceanographic parameters: temperature, pressure, conductivity/salinity, dissolved oxygen, celerity, turbidity, and fluorescence.

The intention of Ifremer is to work under the standards of accreditation when possible, and to develop new scopes of accreditation when none are available.

This quest for quality excellence leads us to use high quality reference devices and methods.

\footnotetext{
a Corresponding author: nolwenn.lamande@ifremer.fr
} 


\subsection{Principle of the $\mathrm{pH}_{\mathrm{T}}$ spectrophotometric method}

The spectrophotometric $\mathrm{pH}_{\mathrm{T}}$ method is described in the Standard Operating procedure 6b (SOP 6b) [2].

The $\mathrm{pH}_{\mathrm{T}}$ is determined by adding $m$-cresol purple indicator dye which colour changes depending on the $\mathrm{pH}_{\mathrm{T}}$. For the sulphonephthalein indicators such as $m$-cresol purple, the acido-basic reaction of interest at sea water $\mathrm{pH}_{\mathrm{T}}$ is the second dissociation:

$$
\mathrm{HI}^{-}{ }_{(\mathrm{aq})}=\mathrm{H}_{(\mathrm{aq})}^{+}+\mathrm{I}^{2-}{ }_{(\mathrm{aq})}
$$

Where I represents the indicator dye.

This dissociation occurs between 7.2 and $8.8 \mathrm{pH}$ unit, which matches to the $\mathrm{pH}_{\mathrm{T}}$ of sea water.

Then, the total hydrogen ion concentration is calculated following the equation:

$$
\mathrm{pH}_{\mathrm{T}}=\mathrm{pK}\left(\mathrm{HI}^{-}\right)+\log _{10} \frac{\left[\mathrm{I}^{2-}\right]}{\left[\mathrm{HI}^{-}\right]}
$$

The different forms of the indicator dye $\left(\mathrm{HI}^{-}\right.$and $\left.\mathrm{I}^{2-}\right)$ have different absorption spectrum, so, the spectral analysis allows to estimate $\frac{\left[\mathrm{I}^{2-}\right]}{\left[\mathrm{HI}^{-}\right]}$and to obtain the value of the $\mathrm{pH}_{\mathrm{T}}$.

\subsection{General illustration of the installation}

The spectrophotometric cells must be temperature regulated and is illustrated in Figure 1.

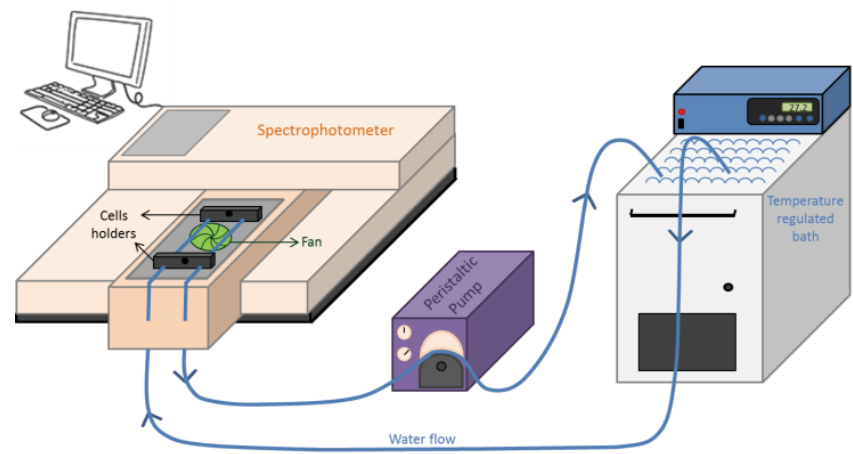

Figure 1: Cells temperature regulation arrangement.

The cell temperature regulation system consists of:

- A Huber temperature regulated bath, model CC130. Its volume is 10 litters (W $x \mathrm{H} \times \mathrm{L}=29 \mathrm{x}$ $11 \times 33 \mathrm{~cm}$ ). This bath can be filled with sea water or fresh water. Its stability and drift are respectively better than $\pm 0.003^{\circ} \mathrm{C}$ and $0.002^{\circ} \mathrm{C}$.

- The spectrophotometric measurement is performed with a double-beam VARIAN CARY $1 \mathrm{C}$ spectrophotometer. It is regularly controlled with a calibration standard set (reference wavelengths are $440 \mathrm{~nm}, 465 \mathrm{~nm}, 546.1 \mathrm{~nm}, 590$ $\mathrm{nm}$, and $635 \mathrm{~nm}$ ). These wavelengths are close to the wavelengths used in the procedure for $\mathrm{pH}_{\mathrm{T}}$ measurement (cf. 4.3.2).

- The spectrophotometric cells are high precision cells with a $10 \mathrm{~cm}$ light path, made of Quartz, with their caps. The volume of cells is $28 \mathrm{~mL}$.
- To adjust temperature in the bath and in the cells, and to control temperature during measurement, two $100 \Omega$ Platinum Resistance Thermometers (PT100) plugged to a Black Stack thermometer readout are installed in the optical chamber of the spectrophotometer. These probes were previously calibrated.

- To inject the $m$-cresol purple indicator dye, a calibrated $10-100 \mu \mathrm{L}$ manual micropipette is used.

The temperature of the sample in the cells is regulated thanks to the bath. The system consists of a peristaltic pump, and drawing tubes in which the bath water regulated at $25^{\circ} \mathrm{C}$ circulates. The drawing tubes are insulated with foam to limit temperature exchanges with the atmosphere. Because of the beam that increases the temperature in the optical chamber, a fan is added to homogenise its temperature.

\section{Protocol}

\subsection{Adjustment of the temperature in the bath and in cells}

\subsubsection{Temperature in the Bath}

The recommendation of the Sop $6 \mathrm{~b}$ is to regulate the temperature in the bath at $25 \pm 0.05^{\circ} \mathrm{C}$. To adjust the temperature of the bath, we use a calibrated thermometer. Figure 2 shows three temperature recordings of the water bath for 30 minutes duration at minimum.

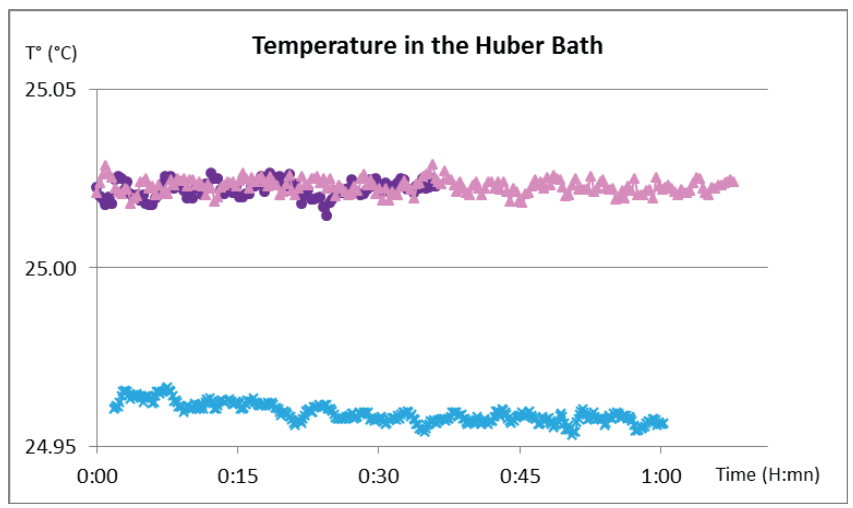

Figure 2: Water temperature recordings in the Huber Bath

The purple rings and pink triangles are with antievaporation insulated balls, and the blue cross, without. The criterion $25 \pm 0.05^{\circ} \mathrm{C}$ is completed in both cases.

However, the use of anti-evaporation balls limits temperature exchanges with room atmosphere, and also the evaporation of the water in the bath. As the volume of the bath is quite small, the evaporation might be a problem, and need to be limited by and anti-evaporation balls.

\subsubsection{Temperature in cells}

Following the Sop $6 \mathrm{~b}$, the temperature in cells should be regulated at $25 \pm 0.1^{\circ} \mathrm{C}$. To check the efficiency of the cell temperature regulation, 2 spectrophotometric cells are 
filled with fresh water, placed in the holders, and a PT100 sensor is introduced in each of them.

For the first experiment, the temperature of the cells is only regulated with the bath (no fan). The spectrophotometer is switched on.

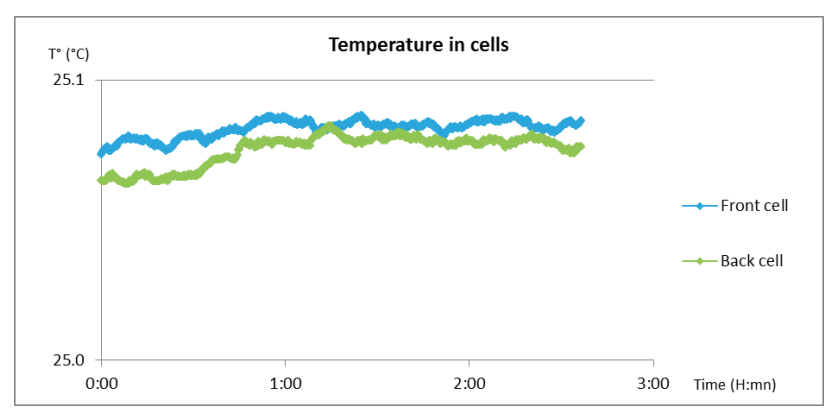

Figure 3: Temperature in cells when temperature is only regulated with the water drawn from the bath (no fan).

This experiment shows that we comply with $25 \pm$ $0.1^{\circ} \mathrm{C}$ in the two cells. Then, a second experiment is performed, to check the temperature with the computer on, and the software loaded:

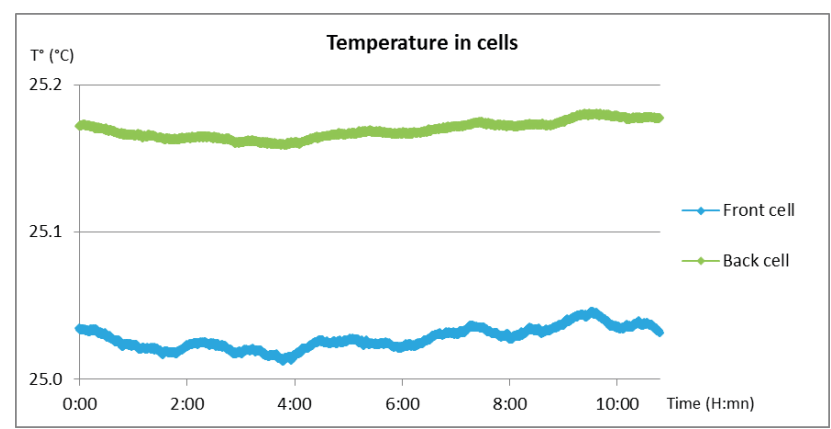

Figure 4: Temperature in cells with the computer on and the software loaded.

In Figure 4 we can see a big difference of temperature between the front cell and the back cell. To reduce this discrepancy, it has been decided to add a fan to homogenize the temperature in the optical chamber.

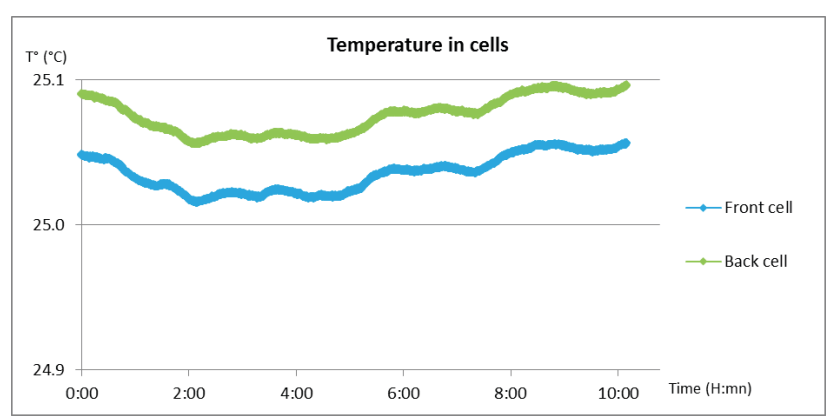

Figure 5: Temperature in cells with the fan on.

Figure 5 shows that the fan resolves the problem of difference of temperature between the two cells. During the 10 hours acquisition, the $25 \pm 0.1^{\circ} \mathrm{C}$ requirement for temperature is fulfilled in both cells.

\subsection{Sampling}

In order to avoid contaminations, the sampling procedure has to be performed quickly. Indeed, the sample should not be in contact with air too long to prevent it from carbon dioxide pollution.

In our case, we fill manually the cells with a pipette. Cells are flushed 3 times with the sample. Then, the sample is introduced in the cells without filling the chimneys. Indeed, a free volume is necessary to allow shaking and thus homogenizing the sample. Afterwards, it will also allow the addition of the indicator dye.

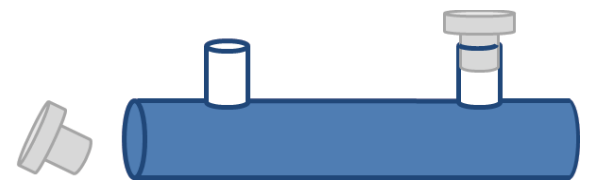

Figure 6: Filling of cells

\subsection{Analyse procedure}

\subsubsection{Sample preparation}

Once the sample is introduced in the spectrophotometric cells, they are placed in a hermetic plastic bag, and immersed in the bath regulated at $25 \pm 0.05^{\circ} \mathrm{C}$ during at least 1 hour.

The warmed sample cells are then removed from the bath; the outside part is cleaned and dried with optical paper. To homogenise sample, they are shaken. Right after shaking, it is necessary to adjust the level of the sample in both chimneys, like shown in Figure 6. Indeed, the interface air/sample must not disturb the beam and give a wrong absorbance value: the difficulty is to find the right quantity of sample to comply with this requirement. Then, cells are rapidly placed in the holders of the spectrophotometer. And 5 minutes minimum is needed before reading the absorbance in order to stabilise the temperature of the sample in cells.

\subsubsection{Absorbances reading}

Absorbances are measured and recorded at three wavelengths:

- $730 \mathrm{~nm}$ : a non-absorbing wavelength

- $578 \mathrm{~nm}$ : the wavelength corresponding to the absorption maxima of the base $\left(\mathrm{I}^{2-}\right)$ form of the $m$-cresol purple

- $434 \mathrm{~nm}$ : the wavelength corresponding to the absorption maxima of the acid $\left(\mathrm{HI}^{-}\right)$form of the $m$-cresol purple.

This operation is repeated three times to estimate the stability of the measures. If a drift is detected, measurements are carried on. Then, the average of the measurements is calculated, and is expressed as $\mathrm{A}_{\lambda, 0}$. It refers to the absorbance value at the wavelength $\lambda$, before addition of dye.

Throughout the procedure, one of the two PT100 probe is used to monitor the temperature in the optical chamber.

\subsubsection{Addition of the m-cresol purple}

The dye is injected with the micropipette into the front cell after removing one of the cell caps. The quantity of dye 
added is commonly between $50 \mu \mathrm{L}$ and $100 \mu \mathrm{L}$. The amount of dye required is that which produces absorbance values between 0.4 and 1.0 at each of the two absorbance peaks. A great care should be taken in order not to leave too much dye at the place of the cap in the chimney. Then, the cap is replaced, the cell is shaken, the sample level in chimney is adjusted, and the cell is finally replaced in its spectrophotometric compartment. The back cell is shaken too.

After waiting 5 minutes minimum, the absorbances are measured again for the same three wavelengths as before. The measurement protocol is the same as described in the paragraph 4.3.2.

For the $730 \mathrm{~nm}$ wavelength, the difference between the absorbance before the addition of dye and after should not be greater than \pm 0.001 . If so, this baseline shift might mean that:

- the cells are not placed in the same way in their holders,

- the levels in chimneys are not balanced as before,

- bubbles appeared in the cells which disturbs the light path of the beam.

Thereafter, the notation $A_{\lambda, \text { dye }}$ will be used to refer to the average of the absorbance values at the wavelength $\lambda$, after addition of dye.

Like in 3.3.2., for each absorbance measurement, a temperature recording in the optical chamber is performed with one of the two PT100 probe.

At the end of the measurements, the second PT100 probe is inserted in one of the cell, and the temperature of the two PT100 is recorded during 15 minutes. This recording will give the temperature difference between the air in the optical chamber, and in the cell. This difference will be used to correct the temperature measured in the optical chamber during the recording of the absorbances. Then, this corrected temperature $T$ will be used to make corrections for the $\mathrm{pH}_{\mathrm{T}}$ calculations.

\section{Calculation of results}

\subsection{Correction of measured absorbances}

For the three wavelengths, subtract absorbances measured without dye from the corresponding absorbances measured after addition of dye:

$$
\begin{aligned}
& A^{\prime}{ }_{434}=A_{434, \text { dye }}-A_{434,0} \\
& A^{{ }^{\prime}{ }_{578}}=A_{578, \text { dye }}-A_{578,0} \\
& A^{\prime}{ }_{730}=A_{730, \text { dye }}-A_{730,0}
\end{aligned}
$$

To correct absorbances value from any baseline shift, subtract the absorbance measured at $730 \mathrm{~nm}$ :

$$
\begin{aligned}
& A_{434}=A^{\prime}{ }_{434}-A^{\prime}{ }_{730} \\
& A_{578}=A^{\prime}{ }_{578}-A^{\prime}{ }_{730}
\end{aligned}
$$

With:

$$
\begin{gathered}
-\log _{10} K_{2}\left[\frac{\varepsilon_{1}\left(\operatorname{Ind}^{2-}\right)}{\varepsilon_{2}\left(\operatorname{HInd}^{-}\right)}\right]=a+\frac{b}{T}+c \ln T-d T \\
T=\text { corrected temperature in Kelvin }
\end{gathered}
$$

Where:

$$
\begin{gathered}
a=-246.64209+0.315971 S+2.8855 \times 10^{-4} S^{2} \\
b=7229.23864-7.098137 S-0.057034 S^{2} \\
c=44.493382-0.052711 S \\
d=0.078134 \\
\frac{\varepsilon_{1}\left(\text { IInd }^{-}\right)}{\varepsilon_{2}\left(\text { IInd }^{-}\right)}=-0.007762+4.5174 \times 10^{-5} \times T \\
\frac{\varepsilon_{2}\left(\text { Ind }{ }^{2-}\right)}{\varepsilon_{1}\left(\text { Ind }^{2-}\right)}=-0.020813+2.60262 \times 10^{-4} \times T \\
\quad+1.0436 \times 10^{-4} \times(S-35) \\
S=\text { practical salinity }
\end{gathered}
$$

\subsection{Correction of addition of the dye}

The addition of indicator dye to the sea water perturbs the $\mathrm{pH}_{\mathrm{T}}$. To minimize this impact, the $\mathrm{pH}$ of the indicator dye solution is adjusted. Nevertheless, it is necessary to add a correction for this addition to obtain the most accurate $\mathrm{pH}_{\mathrm{T}}$ measurements possible.

This correction can be determined experimentally. However, in our case it was given by the leader of the inter-laboratory comparison as follow:

$$
\left[\frac{A_{578}}{A_{434}}\right] \operatorname{corr}=\frac{A_{578}}{A_{434}}+V \times\left[0.125-0.147 \times \frac{A_{578}}{A_{434}}\right]
$$

\section{Results of the inter-laboratory comparison}

\subsection{Context}

The inter-laboratory comparison was organized by the JAMSTEC: the Japan Agency for Marine-earth Science and TEChnology. It was proposed in the framework of a ISO project of normalization of the spectrophotometric $\mathrm{pH}_{\mathrm{T}}$ method. 11 laboratories participated anonymously to the inter-laboratory comparison. The JAMSTEC sent to each laboratory an indicator dye solution (with the correction to apply for the addition of the dye, cf. 5.3), and 5 bottles of sample to analyse.

\subsection{Ifremer results}

Ifremer metrology laboratory analysed the 5 bottles of sample following exactly the procedure previously described. For each bottle, 3 samples were analysed and the $\mathrm{pH}_{\mathrm{T}}$ measured. The results are shown below:

\subsection{Calculation of the $\mathrm{pH}_{\mathrm{T}}$ of sea water}

The $\mathrm{pH}_{\mathrm{T}}$ of sea water is given with the following equation:

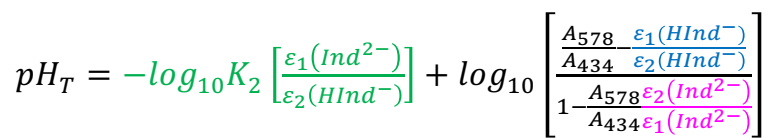




\begin{tabular}{l|r|r|r|r|r|r|r|r}
\hline Sample & 434nmABS & $578 n$ nABS & 730nmABS & $\begin{array}{c}\text { Cell Temp } \\
\left({ }^{\circ} \mathrm{C}\right)\end{array}$ & $R(578 / 434)$ & $\begin{array}{c}\text { Indicator } \\
\text { Volume }(\mathrm{ml})\end{array}$ & pHmeas T & pH at 25C \\
\hline AJ Bottle 058-1 & 0.463 & 0.906 & 0.001 & 25.02 & 1.957 & 0.060 & 7.990 & 7.990 \\
AJ Bottle 058-2 & 0.459 & 0.901 & -0.007 & 25.04 & 1.947 & 0.060 & Excluded value \\
AJ Bottle 058-3 & 0.467 & 0.907 & -0.005 & 25.08 & 1.933 & 0.060 & Excluded value \\
\hline AJ Bottle 186-1 & 0.470 & 0.917 & 0.002 & 24.95 & 1.956 & 0.060 & 7.990 & 7.990 \\
AJ Bottle 186-2 & 0.466 & 0.912 & 0.000 & 25.01 & 1.956 & 0.060 & 7.990 & 7.990 \\
AJ Bottle 186-3 & 0.474 & 0.924 & 0.000 & 25.09 & 1.951 & 0.060 & Excluded value \\
\hline AJ Bottle 250-1 & 0.461 & 0.903 & 0.000 & 25.11 & 1.958 & 0.060 & 7.989 & 7.991 \\
AJ Bottle 250-2 & 0.455 & 0.891 & -0.002 & 25.09 & 1.956 & 0.060 & 7.989 & 7.990 \\
AJ Bottle 250-3 & 0.465 & 0.909 & 0.002 & 25.09 & 1.957 & 0.060 & 7.989 & 7.990 \\
\hline AJ Bottle 326-1 & 0.463 & 0.906 & 0.001 & 25.10 & 1.958 & 0.060 & 7.989 & 7.991 \\
AJ Bottle 326-2 & 0.458 & 0.896 & 0.000 & 25.04 & 1.958 & 0.060 & 7.990 & 7.991 \\
AJ Bottle 326-3 & 0.460 & 0.900 & 0.000 & 25.06 & 1.955 & 0.060 & 7.989 & 7.990 \\
\hline AJ Bottle 328-1 & 0.463 & 0.906 & 0.003 & 24.95 & 1.965 & 0.060 & 7.993 & 7.992 \\
AJ Bottle 328-2 & 0.460 & 0.906 & 0.000 & 24.93 & 1.970 & 0.060 & 7.994 & 7.993 \\
AJ Bottle 328-3 & 0.470 & 0.920 & 0.005 & 25.03 & 1.965 & 0.060 & 7.992 & 7.992 \\
\hline
\end{tabular}

Figure 7: Table of Ifremer metrology laboratory results.

Below, the final results analysed and sent by the JAMSTEC: the metrology laboratory of Ifremer is indicated with the letter $\mathrm{E}$.

\begin{tabular}{|c|r|r|}
\hline Participant & $\mathrm{pH}_{\mathrm{T}}\left(25^{\circ} \mathrm{C}\right)$ average & Standard deviation \\
\hline $\mathrm{A}$ & 7.963 & 0.003 \\
\hline $\mathrm{B}$ & 7.991 & 0.001 \\
\hline $\mathrm{C}$ & 7.915 & 0.014 \\
\hline $\mathrm{D}$ & 7.991 & 0.003 \\
\hline $\mathrm{E}$ & 7.991 & 0.001 \\
\hline $\mathrm{F}$ & 7.990 & 0.004 \\
\hline $\mathrm{G}$ & 7.994 & 0.001 \\
\hline $\mathrm{H}$ & 8.071 & 0.016 \\
\hline $\mathrm{I}$ & 7.993 & 0.002 \\
\hline $\mathrm{J}$ & 7.996 & 0.002 \\
\hline $\mathrm{K}$ & 7.994 & 0.001 \\
\hline
\end{tabular}

Global calculations of all participants excepted outliers:

\begin{tabular}{|c|c|c|c|c|c|c|c|}
\hline Matrix & $/$ & $n$ & $\begin{array}{c}= \\
\mathrm{pH}_{\mathrm{T}}\end{array}$ & $\begin{array}{c}S_{R} \\
\mathrm{pH}_{\mathrm{T}}\end{array}$ & $\begin{array}{c}C_{V, R} \\
\%\end{array}$ & $\begin{array}{c}s_{r} \\
\mathrm{pH}_{\mathrm{T}}\end{array}$ & $\begin{array}{c}C_{V, r} \\
\%\end{array}$ \\
\hline Sea water & 8 & 107 & 7.992 & 0.003 & 0.04 & 0.002 & 0.03 \\
\hline$/$ & Number of laboratories after outlier rejection \\
$x$ & Number of analytical results after outlier rejection \\
$=$ & Overall mean of results (without outliers) \\
$S_{R}$ & Reproductibility standard deviation \\
$C_{V, R}$ & Coefficient of variation of reproductibility \\
$s_{r}$ & Repeatability standard deviation \\
$C_{V, r}$ & Coefficient of variation of repeatability \\
\hline
\end{tabular}

Figure 8: Results of the round robin test.

\subsection{Conclusion}

The results of the metrology laboratory of Ifremer are close $(0.001 \mathrm{pH}$ unit) to the assigned value which was calculated as the average of the results of all participants, excluding outliers. These results validate the set up and protocol used at Ifremer metrology laboratory.

Comparing the results with the oceanographic need of $\pm 0.004 \mathrm{pH}$ unit, we can see that individually, the trueness and standard deviation obtained by the major part of the participants ( 8 on the 11 participants) meet the requirement. However, for this specific exercise, the global accuracy would not fit the criterion.

\section{Conclusions and perspectives}

The implementation of these experiments was the first step to master the spectrophotometric $\mathrm{pH}_{\mathrm{T}}$ protocol, which is known as difficult.

With this experience, we better grasp the tips necessary to implement the protocol (Sop 6b), especially concerning the regulation of temperature, and the handling of the sample.

Moreover, this study allows us to estimate the repeatability values that can be expected. They reveal the quality of the measurement and the mastering of the protocol.

Finally, the use of the calibration standard set to check the spectrophotometer, (its accuracy in wavelength and absorbance, linearity, drift and repeatability), gives us a first idea of the uncertainty components that can be assigned to the spectrophotometric measurements.

Next steps will be the calculation of the uncertainty budget of the method, either following the classic method explained in the Guide to the Expression of Uncertainty in Measurement [3] or by the mean of the results of interlaboratory tests.

This calculation of the uncertainty could be evaluated by the way of an inter-laboratory essay, by the calculation of the reproducibility and the repeatability.

\section{References}

1. ENV05 Publishable-JRP-Summary (Nov 2011)

2. A.G. Dickson, C.L. Sabine, and J.R. Christian, (Eds.) (2007). Guide to best practices for ocean CO2 measurements. PICES Special Publication 3, 191 pp.

3 Evaluation of measurement data - Guide to the expression of uncertainty in measurement - JCGM 100:2008

\section{Acknowledgements}

The authors would like to thank Emmanuel Rinnert from Ifremer for his assistance in the analysis of chemical issues. 